Vol. 3, No. 2, 2017

\author{
Andrii Dzyubyk ${ }^{1}$, Volodymyr Palash ${ }^{2}$, Ivan Khomych ${ }^{3}$, Stanislav Hrynus ${ }^{4}$ \\ ${ }^{1}$ Department of Welding Manufacture, Diagnostics and Restoration of Metal Structures, Lviv Polytechnic \\ National University, 12, S. Bandery Str., Lviv, Ukraine, E-mail: dar.lviv@gmail.com \\ ${ }^{2}$ Department of Welding Manufacture, Diagnostics and Restoration of Metal Structures, Lviv Polytechnic \\ National University, 12, S. Bandery Str., Lviv, Ukraine, E-mail: zvdv@ukr.net \\ ${ }^{3}$ Department of Welding Manufacture, Diagnostics and Restoration of Metal Structures, Lviv Polytechnic \\ National University, 12, S. Bandery Str., Lviv, Ukraine, E-mail: ivankhomych_@ukr.net \\ ${ }^{4}$ Department of Welding Manufacture, Diagnostics and Restoration of Metal Structures, Lviv Polytechnic \\ National University, 12, S. Bandery Str., Lviv, Ukraine, E-mail: slizehollie@gmail.com

\section{OPTIMIZATION OF WELDING MODES FOR HIGH-STRENGTH LOW-ALLOY DOMEX 700 STEEL}

Received: November 15, 2017 / Revised: Decmber 24, 2017 / Accepted: December 26, 2017

(C) Dzyubyk A., Palash V., Khomych I., Hrynus S., 2017

Abstract. The microstructure and hardness of the weld joints of DOMEX 700 steel were investigated. As a result, the optimization of the parameters of robotic arc welding in the environment of protective gases was carried out taking into account the size of the energy per unit length. The optimum modes of welding were determined. The size of the deterioration area, where there is a decrease in hardness in comparison with the main metal, for a thickness of $6 \mathrm{~mm}$ is $2.36 \mathrm{~mm}$, and for a thickness of $3 \mathrm{~mm}$ is $1.51 \mathrm{~mm}$. The parameters of the robotic welding process in the arc mode in the environment of protective gases for the investigated thicknesses of the DOMEX 700 steel were recommended. As a result, the energy-saving conditions for welding performing were achieved ensuring the required technological strength.

Keywords: DOMEX 700 steel; experiment planning; weld joint; microhardness; area of hardening; thermal impact zone; high strength steel; microstructure.

\title{
Introduction
}

The modern state of integration of industry into the world economy requires the development of welding technology for the wide range of alloys and grades of steel. This causes the problems of providing not only weldability and service durability, but power-saving conditions as well. In this case, it is important to take into account the peculiarities of the process of thermal deformation welding period under the certain conditions, since the parameters of welding mode, the techniques of performing certain welded joints and structural-phase composition of the metal in the weld are inseparably linked.

\section{Problem Statement}

To avoid structures worsening the features of weld and to lessen the dimensions of zone of heat impact at lowering power inputs on the process performance is the top priority task at welding highstrength steels. They are especially sensitive to local heating by electric arc and tend to forming so-called soft zones in the heat affected zones (HAZ). As a result, lowering the strength characteristics together with occurrence of residual stresses can cause the initiation and appearance of cracks during the operation mode of a welded construction.

\section{Review of Modern Information Sources on the Subject of the Paper}

Using high-strength low-alloy steel for the industrial production of metalware causes the development of new ways of providing the technological weldability and improving the old ones [1]-[3]. In particular, such features as determination and a purpose of parent metal and availability of additional treatment for providing special properties; taking into account chemical and phase-structure composition of the weld metal; peculiarities of welding techniques; arc spatial position; values and distribution of residual 
stresses etc. [4]-[8] should be considered here. It is also important that the suitability and possibility of additional thermal treatment of weld joints during the process of welding and after it should be considered $[9 ; 10]$. Therefore, the integrated approach to welding should include all these important factors for optimizing the technology and creating energy-saving conditions of the process in general.

\section{Objectives and Problems of Research}

The aim of the work consists in providing the energy-saving conditions of welding for high-strength low-alloy DOMEX 700 steel. It is important that several tasks of the research should be fulfiled, that is, optimizing the parameters of welding mode; studying the influence of heating cycle of welding on forming the phase-structural metal composition of weld joint; analyzing the dimensions of the heat affected zone.

\section{Materials and techniques of the experiment}

The high-strength cold-formed Domex $700 \mathrm{MC}$ steel microalloyed with niobium (Nb), titanium (Ti) and vanadium (V) (see Table 1) was used during the investigations which allows providing a low content of carbon. This steel is characterized by a low amount of inclusions, and is produced by tightly controlled thermomechanical rolling [11].

Table 1

Chemical composition of Domex 700 MC steel

\begin{tabular}{|c|c|c|c|c|c|c|c|c|}
\hline \multicolumn{9}{|c|}{ Content of alloy elements, \% } \\
\hline $\mathrm{C}$ & $\mathrm{Si}$ & $\mathrm{Mn}$ & $\mathrm{P}$ & $\mathrm{S}$ & $\mathrm{Al}$ & $\mathrm{Nb}$ & $\mathrm{V}$ & $\mathrm{Ti}$ \\
\hline 0.12 & 0.10 & 2.10 & 0.025 & 0.010 & 0.015 & 0.09 & 0.2 & 0.15 \\
\hline
\end{tabular}

As a result, not only excellent mechanical properties (Table 2), but also good technological weldability can be achieved.

Mechanical properties of Domex $700 \mathrm{MC}$ steel [11]

Table 2

\begin{tabular}{|c|c|c|c|c|c|c|}
\hline Tensile & Yield & \multicolumn{2}{|c|}{ Elongation, $\%$} & \multicolumn{3}{|c|}{ Bending radius } \\
\cline { 3 - 7 } strength, & strength, & $\delta>3 \mathrm{~mm}$ & $\delta<3 \mathrm{~mm}$ & $\delta \leq 3 \mathrm{~mm}$ & $3<\delta \leq 6 \mathrm{~mm}$ & $\delta>6 \mathrm{~mm}$ \\
\hline$\sigma_{B}, \mathrm{MPa}$ & $\sigma_{T}, \mathrm{MPa}$ & & 12 & $0.8 \cdot \delta$ & $1.2 \cdot \delta$ & $1.6 \cdot \delta$ \\
\hline $750-950$ & 700 & 10 & 12 &
\end{tabular}

where $\delta$ is metal thickness.

Data from Table 2 show a good yieldability of this steel, so that it can be bended lengthwise as well as along the rolling direction with minimum bending radii.

Butt-welded joints of the elements with thickness of $3 \mathrm{~mm}$ and $6 \mathrm{~mm}$ were investigated. They were obtained on a bench tester by using a Panasonic welding robot (Volk Weld). Cutting of rectangular plates with the dimensions $250 \mathrm{~mm} \times 150 \mathrm{~mm}$ was performed with the use of Trumpf 5030 laser cutting machine. As a filler material, the wire EN ISO 16834-A: G 694 M21 Mn3Ni1CrMo of $1 \mathrm{~mm}$ in diameter was chosen along with gas mixture M21 (80\% Ar + 20\% CO2) according to Ukrainian State Technological Standard ISO 14175:2004.

Before welding, the elements were immobilized with the use of manual mechanical clamps and tack welds (Fig. 1).

The use of robot welding enables eliminating the influence of such a subjective human factor as the qualification of a welder and providing tight control of rate of energy input of the process. It also allows obtaining the uniform chemical composition of the weld joint along its axis.

The investigation of microstructure of the weld joint was performed on the microsections produced by cutting the weld joint across the weld into templates and further grinding and polishing them according to a standard technique. For etching the microsections a $4 \%$ solution of $\mathrm{HNO}_{3}$ in the ethanol was used. Microstructures were investigated with a metallurgical microscope MИМ - 8M3i with a 1000x magnification range. The prepared microsections being investigated, hardness was measured by the Vickers hardness test pressing a diamond pyramid at the load of $10 \mathrm{~kg}$, as well as at $100 \mathrm{~g}$ while using a micro-hardness tester ПМТ-3. 

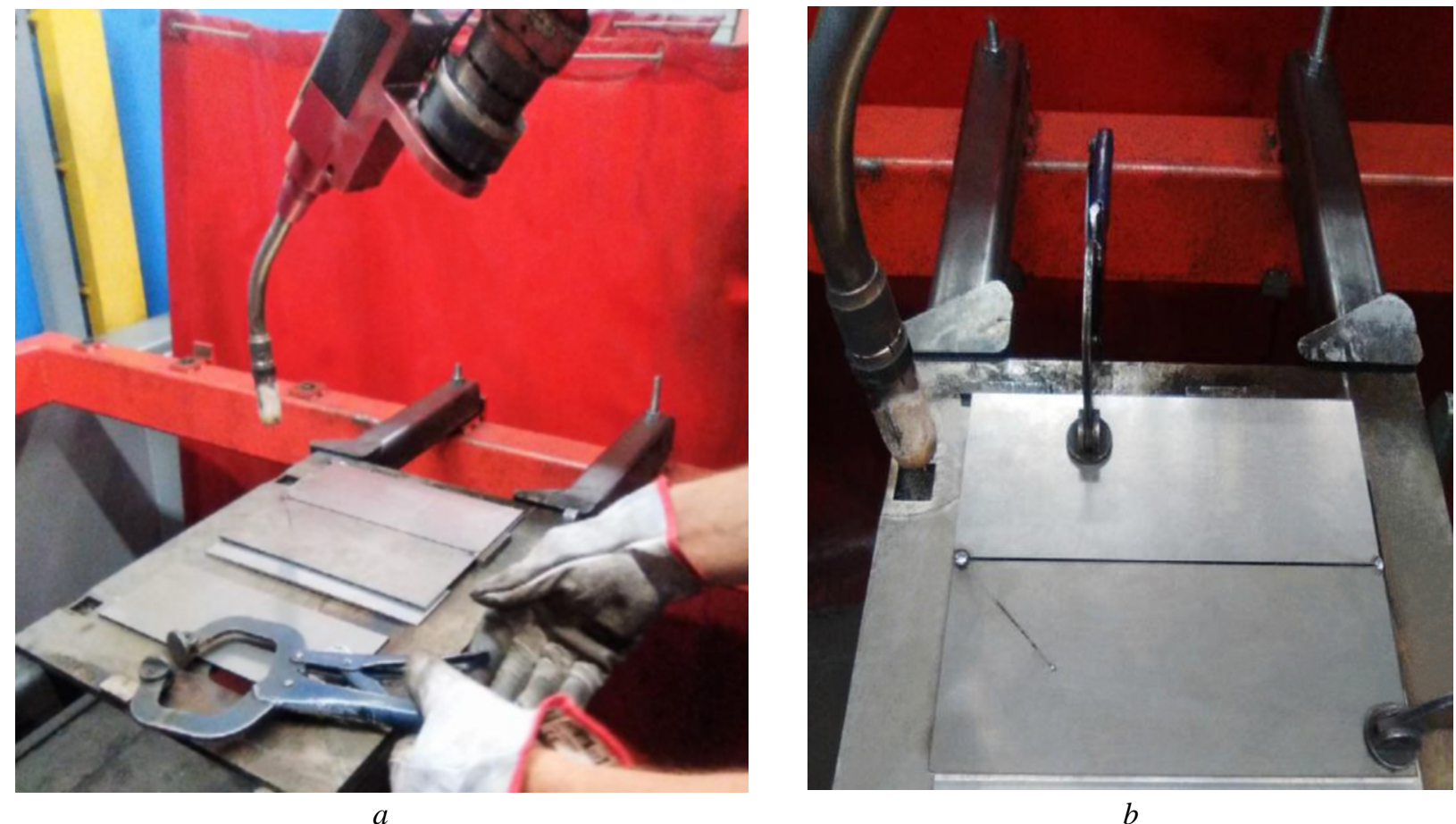

Fig. 1. Preparing the elements for welding: $a$-location on the bench tester; $b$-tack welds performed by the welding robot

The optimal parameters of the mode were set basing on planning and performing the series of sequential experiments. The technique shown in specialized literature $[12 ; 13]$ was performed on the base of a full-factor experiment. As a response function (Y), the dimensions of the heat affected zone of the weld joints were accepted. For this, the macrostructure analysis of the templates cut mechanically from the middle part of welded plates was carried out. In addition, the following qualitative features of obtained joints were analyzed: forming the back of weld, occurrence of electrode metal splashing and its magnitude, possible welding defects, residual welding deformations. After welding, visual inspection including the measurement of the dimensions of all plates was performed (Fig. 2). These characteristics are not a part of the response function, but they influenced the set of mode parameters based on the expert evaluation, since they have an effect not only upon the construction workability, but also on the ergonomic characteristics of the product in general.

Heat effect of the process was also studied on the series of single short welds according to the developed plan of the experiment. It made it possible to determine the arc power and the conditions of heat sink quite accurately by the width of the zones of heat tints (Fig. 2).

Such key elements of arc process as arc voltage $\left(\mathrm{X}_{1}\right)$, welding speed $\left(\mathrm{X}_{2}\right)$ and welding current $\left(\mathrm{X}_{3}\right)$ were accepted as impact factors. Their values and possible range of changes are shown in Table 3.

Table 3

Factor values and range of their changes during welding the plates of different thickness

\begin{tabular}{|c|c|c|c|c|c|c|}
\hline \multirow{2}{*}{ Impact factors } & \multicolumn{2}{|c|}{ Arc voltage, $V\left(X_{1}\right)$} & \multicolumn{2}{|c|}{$\begin{array}{l}\text { Welding speed, } \mathrm{mm} / \mathrm{sec} \\
\left(\mathrm{X}_{2}\right)\end{array}$} & \multicolumn{2}{|c|}{ Welding current, $\mathrm{A}\left(\mathrm{X}_{3}\right)$} \\
\hline & $\delta=3 \mathrm{~mm}$ & $\delta=6 \mathrm{~mm}$ & $\delta=3 \mathrm{~mm}$ & $\delta=6 \mathrm{~mm}$ & $\delta=3 \mathrm{~mm}$ & $\delta=6 \mathrm{~mm}$ \\
\hline Main level & 18 & 24 & 9.7 & 5.0 & 125 & 200 \\
\hline Change range $\left(\Delta \mathrm{x}_{\mathrm{i}}\right)$ & 3 & 3 & 3.3 & 0.55 & 5 & 20 \\
\hline
\end{tabular}




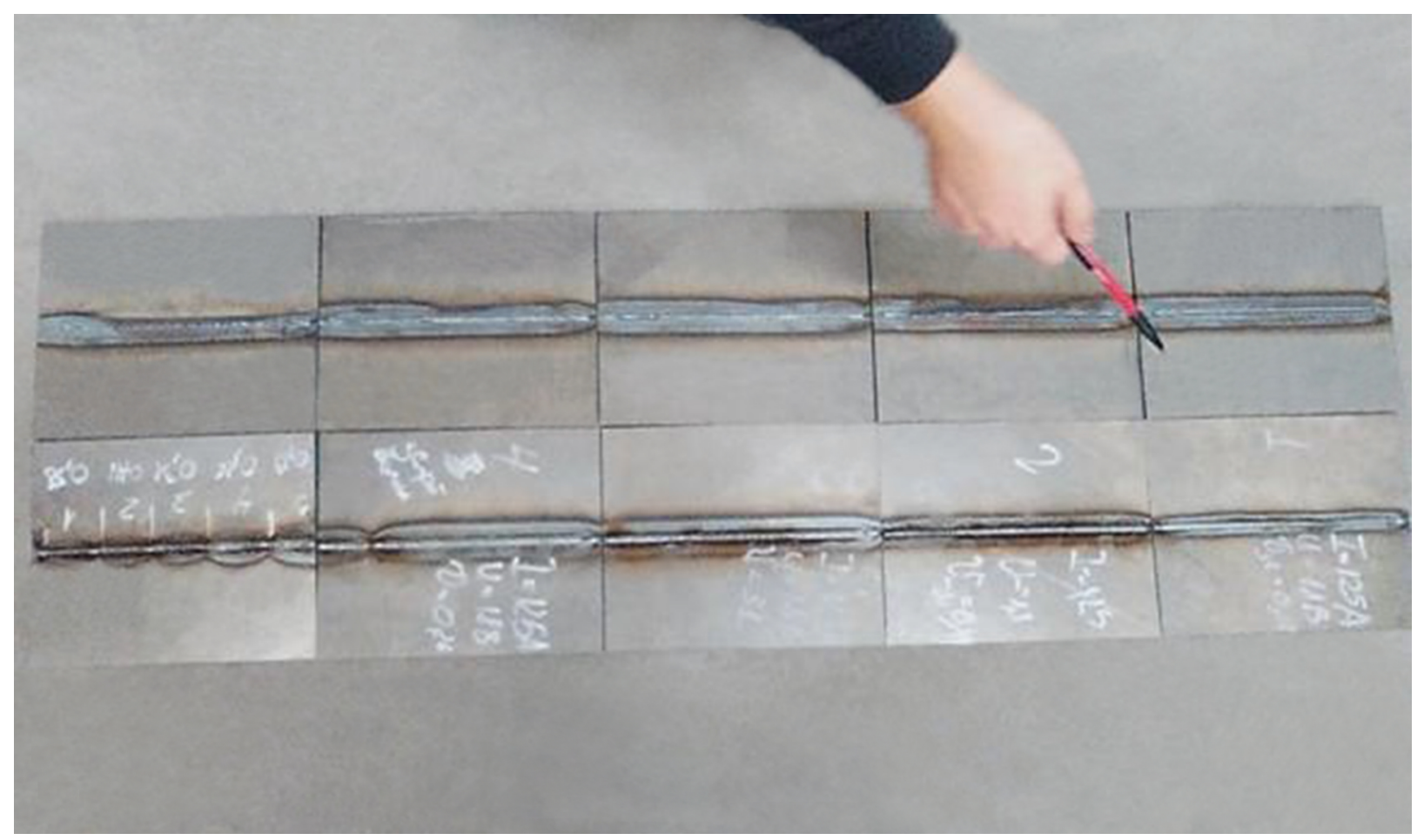

Fig. 2. Visual inspection of experimental templates

Below, the plan of experiment $[12 ; 13]$ containing the record of all factor combinations or their parts in the encoded form (so-called design matrix) is shown (Table 4).

Table 4

Design matrix for the experiment including three factors for plates of different thickness

\begin{tabular}{|c|c|c|c|c|c|}
\hline \multirow{2}{*}{ Experiment number } & \multirow{2}{*}{$\mathrm{X}_{1}$} & $\mathrm{X}_{2}$ & $\mathrm{X}_{3}$ & \multicolumn{2}{|c|}{$\mathrm{Y}, \mathrm{mm}$} \\
\cline { 3 - 6 } & & & & & \multicolumn{2}{c|}{$\delta \mathrm{mm}$} & $\delta=6 \mathrm{~mm}$ \\
\hline 1 & +1 & +1 & +1 & 1.6 & 2.6 \\
\hline 2 & -1 & +1 & +1 & 2.7 & 3.9 \\
\hline 3 & +1 & -1 & +1 & 2.3 & 2.5 \\
\hline 4 & -1 & -1 & -1 & 1.6 & 2.1 \\
\hline 5 & +1 & +1 & -1 & 1.5 & 1.6 \\
\hline 6 & -1 & +1 & -1 & 2.6 & 2.7 \\
\hline 7 & +1 & -1 & -1 & 2.2 & 1.9 \\
\hline
\end{tabular}

Possible negative effects occurring due to the wear of current-carrying nozzle (weld current oscillation), slipping of wire in wire feed rollers (voltage oscillation), imperfection of positioning and moving (welding speed) were not recorded.

The results of the investigation show that the best forming of weld joint was obtained in experiments № 2, 5 and 6 for templates with thickness of $3 \mathrm{~mm}$, and № 2, 6 and 8 for templates $6 \mathrm{~mm}$ thick. However, if the qualitative factors of the process based on the performed expert evaluation are taken into account, it is advisable to address the data of the experiments 2 and 8 for the templates 3 and $6 \mathrm{~mm}$ thick respectively.

As a result of performed investigations, the following parameters of the process of robot welding with the use of electrode wire $1.0 \mathrm{~mm}$ in diameter were determined (Table 5).

Microstructural analysis. Microstructure of different zones of weld joint, heat affected zones and parent metal was investigated (Fig. 3). The microstructure of parent metal contains a ferritic matrix with 
the deposition of special carbides of molybdenum, vanadium and titanium (Fig. 4). Its hardness is, at an average, $270 \mathrm{HV}$. In the heat affected zone, two areas were revealed: the area of recrystallization of coldworked parent metal (Fig. 5) and the area of total recrystallization (Fig. 6). On the area of recrystallization, such phenomena as rest, recovery, polygonization and initial recrystallization take place and cause the decrease in hardness to $220 \mathrm{HV}$. On the area of total recrystallization, which was heated over $\mathrm{Ac}_{3}$ to the austenite state, special carbides are dissolved and then, while cooling, the transformation of austenite to ferrite takes place. In this zone, microstructure is ferrite-carbide, and the size of ferrite and carbide grains gradually increases with the increase in temperature while approaching to the weld joint. The hardness in this area is somewhat higher in comparison with the recrystallization zone and approaches $240 \mathrm{HV}$, but in all cases, it is lower than in parent metal on average by 30 units.

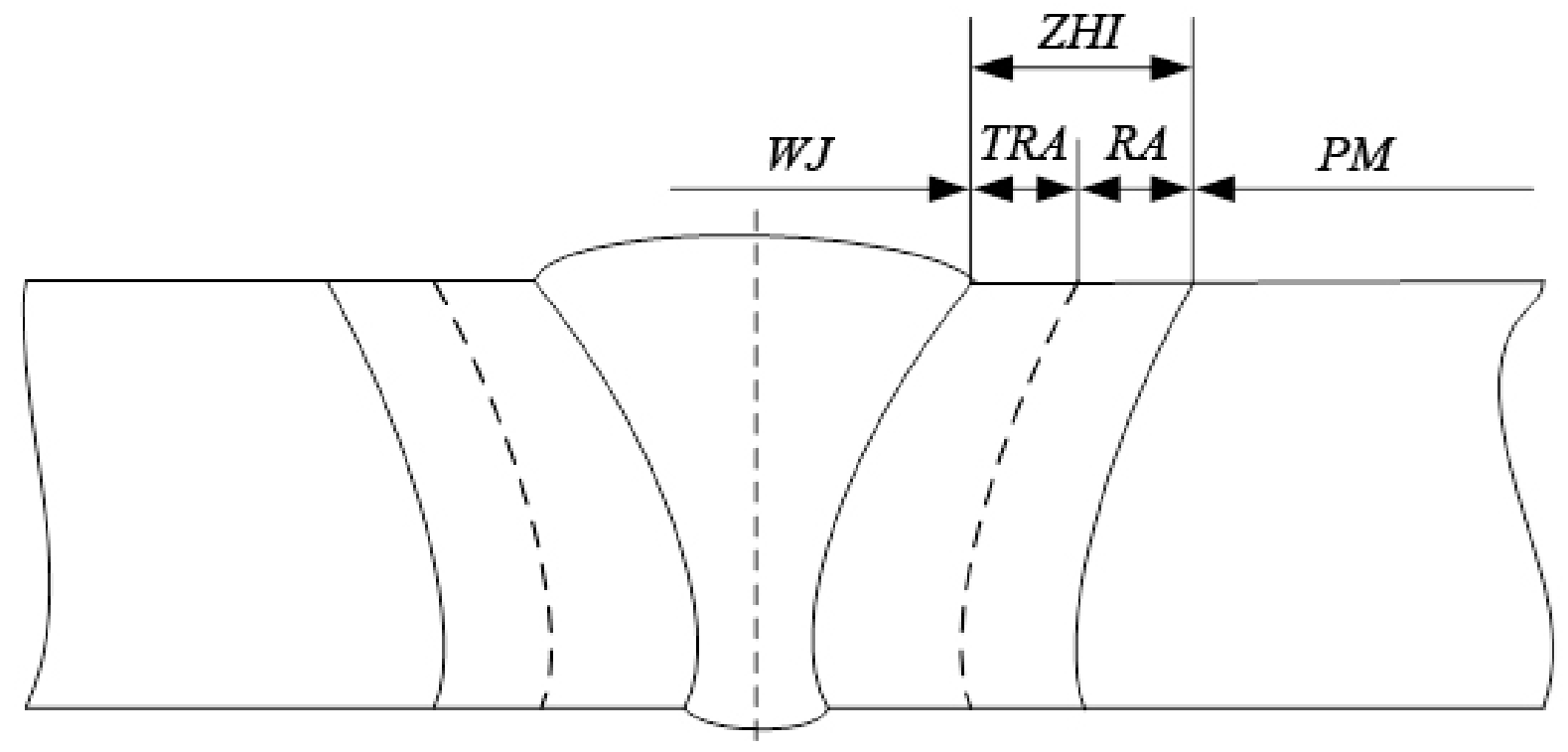

Fig. 3. Diagram of butt weld: WJ-weld joint; ZHI-zone of heat impact; $T R A$ - total recrystallization area; $R A$ - recrystallization area; $P M$ - parent metal

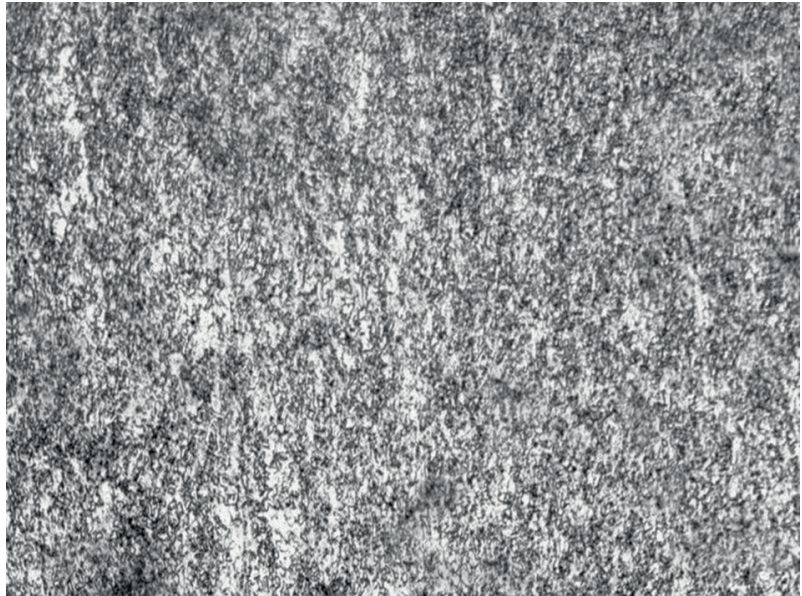

Fig. 4. Microstructure of parent metal $($ DOMEX steel $700(\times 300))$

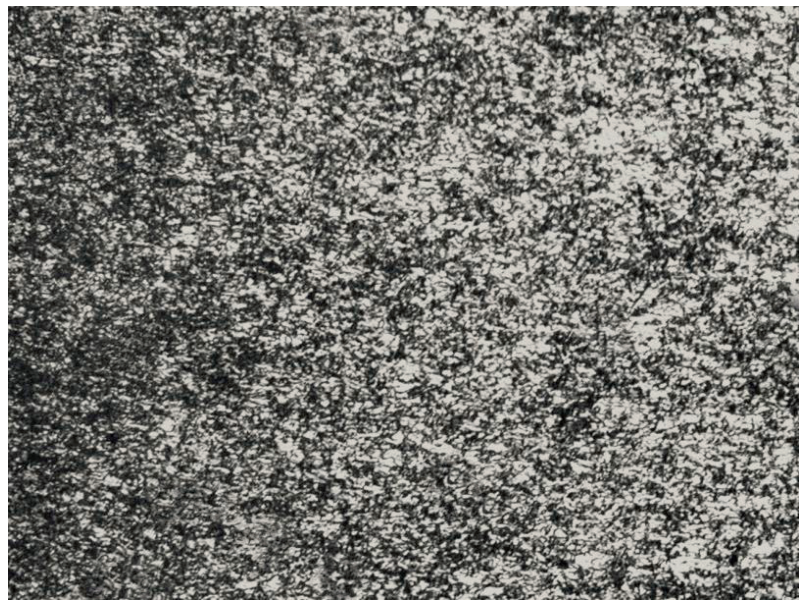

Fig. 5. Microstructure of recrystallization area of a heat affected zone in the weld joint $(\times 300)$

On the fusion zone, which by its chemical composition is the transition zone from heat affected zone to the weld joint, some undesirable phenomena, as carbide or martensite structures and cracks can occur, but no such defects were detected in the investigated templates (Fig. 7). 
Microstructure of the weld joint has an obviously columnar pattern. At the boundaries of previous austenite zones having had columnar pattern, ferrite is noticed to appear. In the weld joint besides the ferrite phase, carbide deposition can be observed (Fig. 8).

Therefore, the microstructure in all zones of weld joint is considered as the mixture of ferrite and carbide phases, which are different from each other in size and amount.

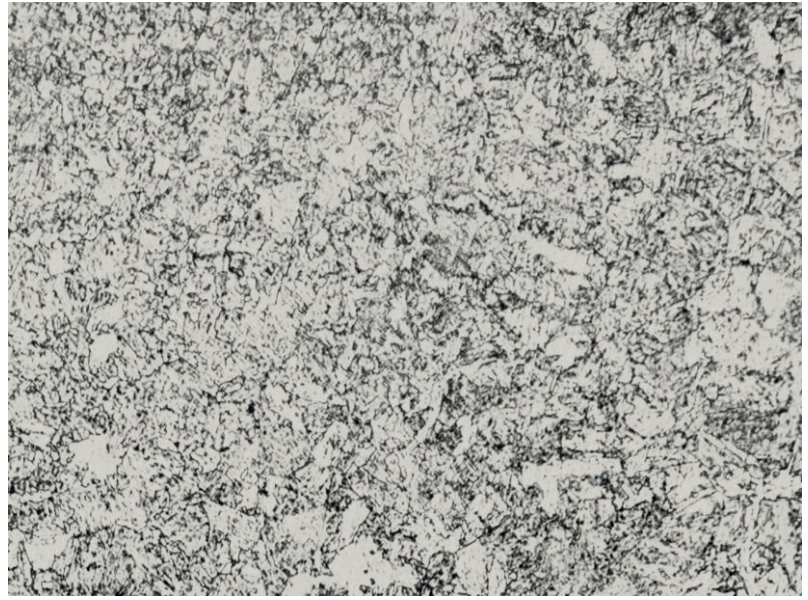

Fig. 6. Microstructure of the total recrystallization area of a heat affected zone in the weld joint (x 300)

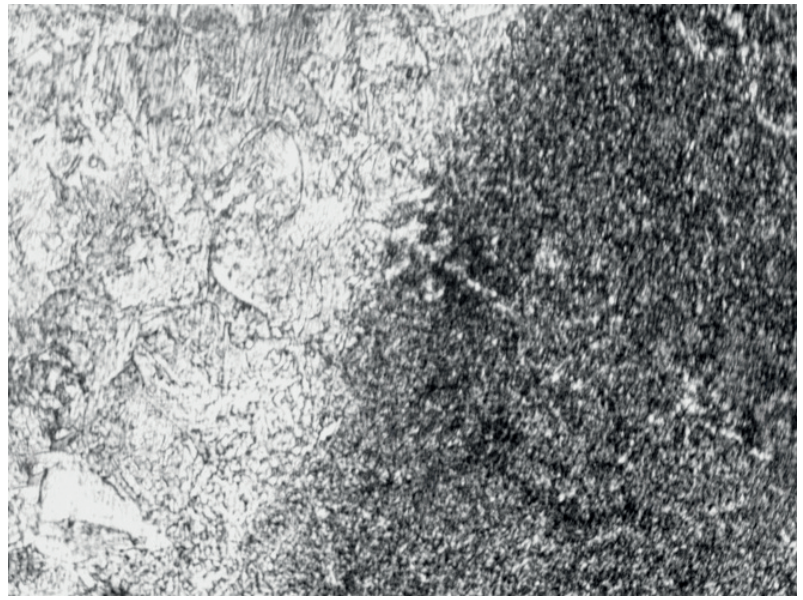

Fig. 7. Microstructure of the fusion zone (x 300)

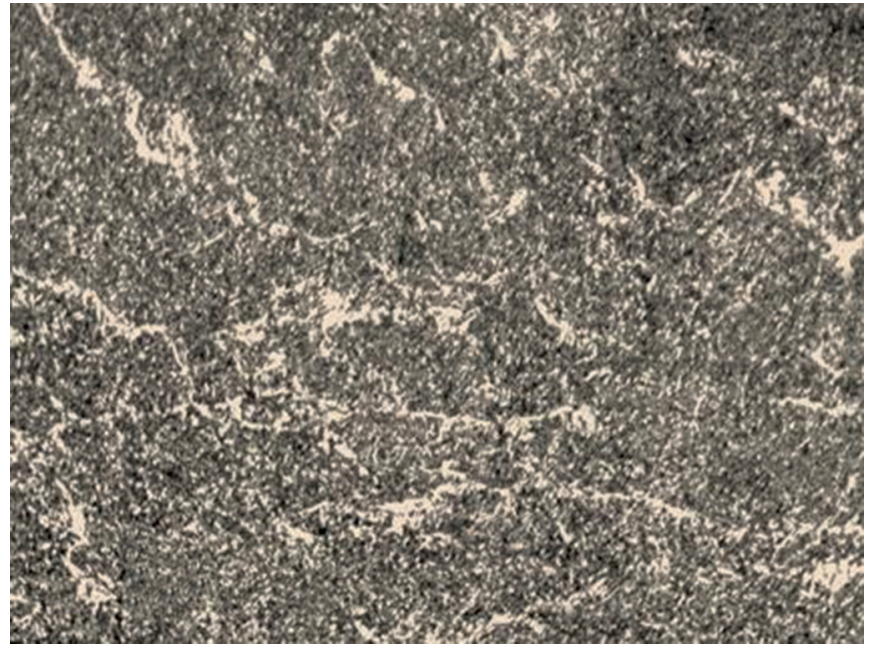

Fig. 8. Weld microstructure (x 300)

The dimensions of areas of total recrystallization and recrystallization were measured on all investigated templates with an incremental step of $50 \mu \mathrm{m}$. Depending on welding modes, their dimensions for a thickness of $6 \mathrm{~mm}$ are in the range from 1.6 to $4 \mathrm{~mm}$, and for a thickness of $3 \mathrm{~mm}$ - from 1.5 to $2.7 \mathrm{~mm}$ (Fig. 9).

The investigations of microstructure and hardness of weld joint between DOMEX 700 steel templates definitely indicate that in the heat affected zone the hardness is slightly lower comparing with carbon steels and low-alloy steels, which is caused by the absence of hardening structures such as martensite or bainite in it. Instead of them, there is a ferrite-carbide structure there, as in the parent metal. In this zone hardness is lower than in parent metal, since its strengthening is lower than one created during previous cold forming. 


\section{Conclusions}

The phase-structure composition of metal of weld joints made for high-strength low-alloy DOMEX 700 steel was investigated. It has been shown that the heating cycle of welding causes the creation of soft zones while forming the ferrite metal structure containing carbide inclusions. The dimensions of the soft zone are determined by the arc power during the robot welding process.

The optimization of the parameters of robot arc welding in shielding gases with taking into account the value of energy input was carried out. For optimal welding modes, the size of a heat affected zone (soft zone), where the decrease in hardness in compare with parent metal is observed, is $1.9 \mathrm{~mm}$ for a thickness of $6 \mathrm{~mm}$ and $1.6 \mathrm{~mm}$ for a thickness of $3 \mathrm{~mm}$.

The parameters of the mode of robot arc welding process in the medium of shielding gases for investigated values of DOMEX 700 steel thickness were recommended. As the result of their implementation, the energy-saving conditions for welding with providing the necessary technological hardness are achieved.

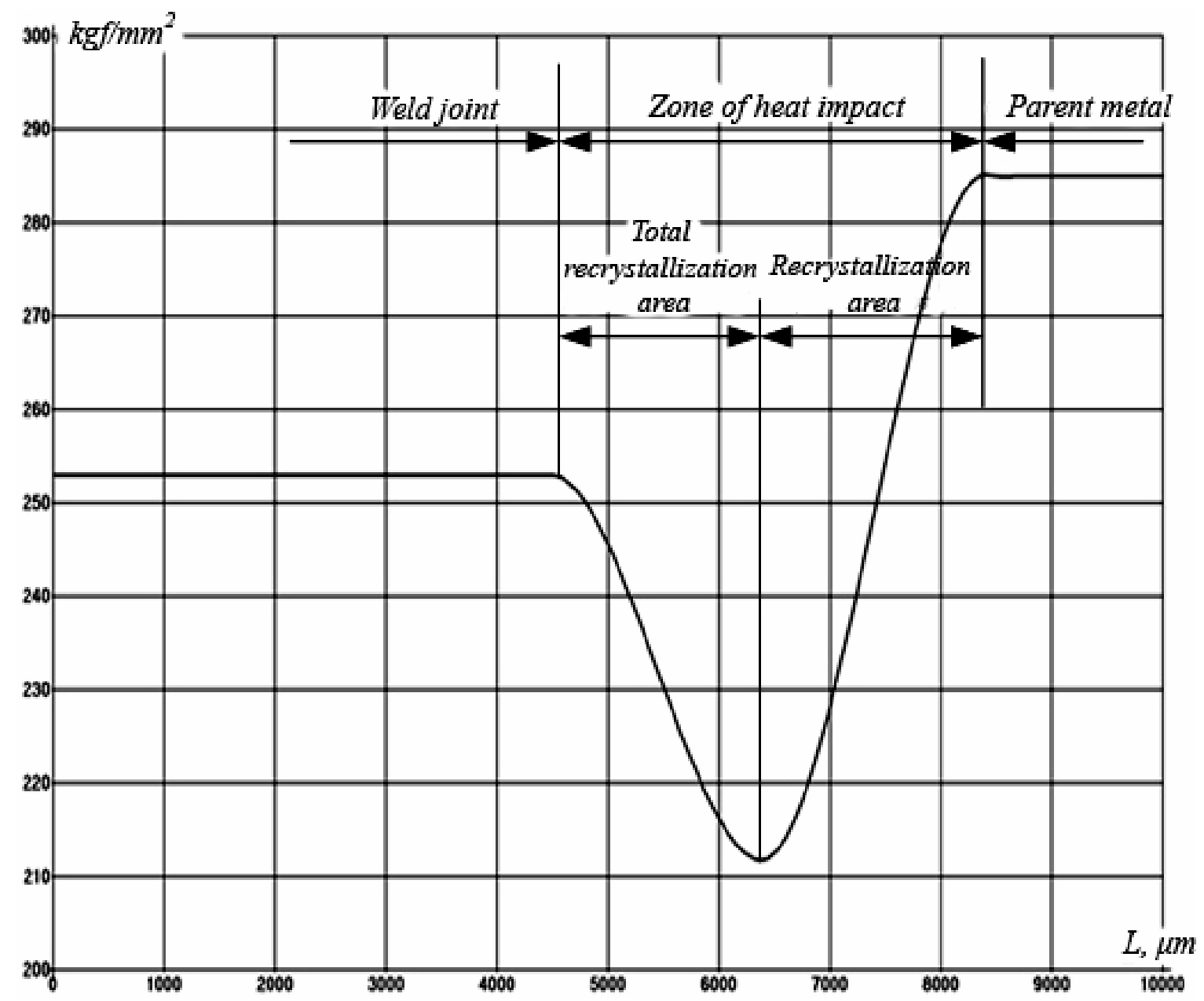

Fig. 9. Graph of distribution of micro-hardness of weld joint

\section{References}

[1] V.M. Palash , et al., "Osoblyvosti budovy zvarnoho z'iednannia zi stali typu 35 XM, z austenitnym shvom" ["Features of the structure of welded joints made of steel type $35 \mathrm{XM}$, with austenitic suture"], Visnyk Natsionalnoho universytetu "Lvivska politekhnika" "Dynamika, mitsnist ta proektuvannia mashyn i pryladiv" [Bulletin of Lviv Polytechnic National University "Dynamics, strength and design of machines and devices”], no. 866, pp. 21-25, 2017. [in Ukrainian]. 
[2] A. R. Dziubyk and L. V. Dziubyk, "Zabezpechennia enerhooshchadnykh umov formuvannia zvarnykh z'iednan pidvyshchenoi mitsnosti" ["Provision of energy-saving conditions for the formation of welded joints of high strength"], Tezy dopovidei II-i Mizhnarodnoi naukovo-tekhnichnoi konferentsii "Enerhooshchadni mashyny $i$ tekhnolohii" [ Abstracts of the 2nd International Scientific and Technical Conference "Energy-saving Machines and Technologies”], Kyiv, Ukraine, 2015, p. 78. [in Ukrainian].

[3] M. H. Yefimenko, "Zvariuvannia spetsialnykh stalei i splaviv" ["Welding of special steels and alloys"], Kharkiv, Ukraine: FOP Marakin I.V. Publ., 2007. [in Ukrainian].

[4] E. L. Makarov, "Holodnye treshhiny pri svarke legirovannyh stalej" ["Cold cracks in the welding of alloy steels”], Moscow, Russia: Mashinostroenie Publ., 1981. [in Russian].

[5] A. R. Dzyubyk, et al., "Pidvyshchennia efektyvnosti zvariuvannia mahistralnykh truboprovodiv pry yikh ekspluatatsii ta remonti" ["Increasing the efficiency of welding of main pipelines during their operation and repair”], Lviv, Ukraine: Spolom Publ., 2013. [in Ukrainian].

[6] A. R. Dzyubyk, et al., "Influence of Residual Stresses on the Limit Equilibrium of a Pipeline with Internal Crack of Arbitrary Configuration”, Materials Science, vol.52, no.1, pp. 89-98, July, 2016.

[7] L. M. Lobanov, et al., "Osobennosti protekanija termodeformacionnyh processov pri dugovoj svarke vysokoprochnyh stalej" ["Features of the course of thermoformation processes during arc welding of high strength steels"], Avtomaticheskaja svarka [Automatic welding], no. 3, pp.13-17, 1999. [in Russian].

[8] L. M. Lobanov, et al., "Obrazovanie holodnyh treshhin v svarnyh soedinenijah vysokoprochnyh stalej s predelom tekuchesti 350-850 MPa" ["Formation of cold cracks in welded joints of high-strength steels with a yield strength of 350-850 MPa”], Avtomaticheskaja svarka [Automatic welding], no.7, pp. 8-13, 2013. [in Russian].

[9] V. M. Palash, et al., "Osoblyvosti zvariuvannia spetsialnykh vysokomitsnykh stalei bez zastosuvannia poperednoho pidihrivannia" ["Features of welding of special high-strength steels without the use of preheating"], Materialy 12-ho Mizhnarodnoho sympoziumu ukrainskykh inzheneriv-mekhanikiv u Lvovi [Proceedings of the 12th International Symposium of Ukrainian Mechanical Engineers in Lviv], Lviv, Ukraine, 2015, pp. 101-102. [in Ukrainian].

[10] M. H. Shorshorov and V. V. Belov, "Fazovye prevrashhenija i izmenenie svojstv stali pri svarke" ["Phase transformations and changes in the properties of steel during welding"], Moscow, Russia: Nauka Publ., 1972. [in Russian].

[11] SSAB SWEDISH STEEL. Domex range of hot-rolled high strength sheet steel. Sweden, 24 p., 2015.

[12] A. R. Dzyubyk, et al., "Zabezpechennia tekhnolohichnoi mitsnosti zvarnykh stykiv obsadnykh trub" ["Provision of technological strength of welded joints of casing pipes"], "Avtomatyzatsiia vyrobnychykh protsesiv u mashynobuduvanni ta pryladobuduvanni" ["Automation of production processes in mechanical engineering and instrument making"], no. 50, pp. 94-102, 2016. [in Ukrainian].

[13] K. L. Kulikovskij and V. Ja. Kuper, "Metody i sredstva izmerenij" [ "Methods and measuring measurement”], Moscow, Russia: Jenergoatomizdat Publ., 1986. [in Russian].

[14] V. M. Palash, "Metaloznavchi aspekty zvarnosti zalizovuhletsevykh splaviv" ["Metallurgical aspects of welded iron-carbon alloys”], Lviv, Ukraine: KINPATRI LTD Publ., 2003. [in Ukrainian]. 